\title{
Karyotype analysis in Bignonieae (Bignoniaceae): chromosome numbers and heterochromatin
}

\author{
JOEL M.P. CORDEIRO ${ }^{1}$, MIRIAM KAEHLER ${ }^{2}$, GUSTAVO SOUZA ${ }^{3}$ and LEONARDO P. FELIX ${ }^{1}$ \\ ${ }^{1}$ Centro de Ciências Agrárias, Departamento de Ciências Biológicas, Universidade Federal \\ da Paraíba, Campus II, Rodovia PB 079, Km 12, 58397-000 Areia, PB, Brazil \\ ${ }^{2}$ Mülleriana, Sociedade Fritz Müller de Ciências Naturais, Rua Humberto Morona, 26, 80050-402 Curitiba, PR, Brazil \\ ${ }^{3}$ Centro de Ciências Biológicas, Departamento de Botânica, Universidade Federal de Pernambuco, \\ Campus I, Av. Prof. Moraes Rego, 1235, 50670-901 Recife, PE, Brazil
}

Manuscript received on May 18, 2017; accepted for publication on July 31, 2017

\begin{abstract}
Chromosome numbers and heterochromatin banding pattern variability have been shown to be useful for taxonomic and evolutionary studies of different plant taxa. Bignonieae is the largest tribe of Bignoniaceae, composed mostly by woody climber species whose taxonomies are quite complicated. We reviewed and added new data concerning chromosome numbers in Bignonieae and performed the first analyses of heterochromatin banding patterns in that tribe based on the fluorochromes chromomycin A3 (CMA) and 4'-6-diamidino-2-phenylindole (DAPI). We confirmed the predominant diploid number $2 n=40$, as well as variations reported in the literature (dysploidy in Mansoa $[2 n=38]$ and polyploidy in Dolichandra ungis-cati $[2 n=80]$ and Pyrostegia venusta $[2 n=80])$. We also found a new cytotype for the genus Anemopaegma (Anemopaegma citrinum, $2 n=60$ ) and provide the first chromosome counts for five species (Adenocalymma divaricatum, Amphilophium scabriusculum, Fridericia limae, F. subverticillata, and Xylophragma myrianthum). Heterochromatin analyses revealed only GC-rich regions, with six different arrangements of those bands. The A-type (one large and distal telomeric band) were the most common, although the presence and combinations of the other types appear to be the most promising for taxonomic studies.
\end{abstract}

Key words: Cytotaxonomy, fluorochromes, neotropical lianas, ploidy variation.

\section{INTRODUCTION}

Bignonieae is the largest tribe in Bignoniaceae, comprising more than 393 species in 21 genera (Lohmann and Ulloa 2017). While Bignoniaceae is Pantropical, Bignonieae is exclusively Neotropical, occurring from southern United States through

Correspondence to: Joel M.P. Cordeiro

E-mail: joelmpcordeiro@yahoo.com.br northeastern Chile and central-northern Argentina; several of its species are restricted to Brazil (Gentry 1980, Lohmann and Taylor 2014). The tribe is characterized by lianas (sometimes shrubs or small trees), wood with cambial variants forming four to 32 phloem arcs or wedges, compound and opposite leaves with the terminal leaflet often replaced by a tendril, and septicidal capsules (Lohmann and Taylor 2014). 
Phylogenetic studies in Bignoniaceae have shown that Bignonieae is a strongly supported clade, sister to a not well-supported clade with two lineages mostly composed of arboreal species: one lineage with Catalpeae and Oroxyleae, and the other with the informal Crescentiina clade (Olmstead et al. 2009). Although the tribe Bignonieae is very well established, the classification of its genera has always been challenging (Gentry 1980, Lohmann and Taylor 2014). Molecular phylogenetic studies have shown that previous generic system did not reflect evolutionary relationships between lineages within the tribe. Forty-seven genera were previously recognized, but only 21 lineages were retrieved (Lohmann 2006). Among those lineages, six reflected genera that kept their previous circumscriptions (Anemopaegma, Lundia, Martinella, Pyrostegia, Styzophyllum, and Tynanthus). The remaining species were combined into 15 genera with broader circumscriptions that are now recognizable by previously unused synapomorphies (Lohmann and Taylor 2014). Despite this new and robust system, some of the genera whose circumscriptions were altered are morphologically very close, and it remains difficult to distinguish them (Lohmann and Taylor 2014).

Most Bignonieae species have very stable chromosome numbers. Approximately $85 \%$ of the species studied showed $2 n=40$ (Goldblatt and Gentry 1979, Piazzano 1998, Firetti-Leggieri et al. 2011, 2013, Piazzano et al. 2015, Cordeiro et al. 2016a), although some species show variant ploidies, such as Pyrostegia venusta (Ker Gawl) Miers $(2 n=40,60$, and 80; Joshi and Hardas 1956, Piazzano 1998, Cordeiro et al. 2016a), Dolichandra unguis-cati (L.) L. G. Lohmann ( $2 n$ $=40$ and 80; Goldblatt and Gentry 1979, Piazzano 1998, Cordeiro et al. 2016a), in addition to some Anemopaegma species with $2 n=40$ and 80 (FirettiLeggieri et al. 2011, 2013). Dysploidy was also observed in Mansoa, with $2 n=38$ being observed in M. hymenaea (DC.) A. H. Gentry (Simmonds
1954) and M. difficilis (Cham.) Bureau \& K. Schum. (Cordeiro et al. 2016a). It is also speculated that the chromosome numbers in some species of Anemopaegma (Firetti-Leggieri et al. 2011, 2013) may reflect allopolyploidy, as some individuals of distinct species have intermediate morphologies.

In addition to morphology and chromosome numbers, important tools for karyotypic characterization in plants are variations in the quantities, distributions, and compositions of their constitutive heterochromatin. The fluorochromes Chromomycin A3 (CMA) and 4'6-diamidino-2phenylindole (DAPI) are widely used for those studies. Both fluorochromes are used with the same specimens, resulting in differential coloring patterns: CMA stains GC-rich regions, whereas DAPI stains only AT-rich regions (Guerra 2000). This type of analysis has been used to distinguish the cytotypes of species belonging to different hierarchical levels, such as families (Cordeiro et al. 2017), species of the same genus (Almeida et al. 2007, 2016, Cordeiro et al. 2016b), and even cultivars and populations of the same species (Dematteis et al. 2006, Romero-da Cruz et al. 2015, Begum and Alam 2016).

We considered here the heterochromatin patterns of 24 species of Bignonieae based on the fluorochromes chromomycin A3 (CMA) and 4'-6-diamidino-2-phenylindole (DAPI), as well as variations in the chromosome numbers of 62 species of the tribe (including variations due to polyploidy and disploidy). We discuss the variations found among heterochromatin patterns as well as those of chromosome numbers in the tribe, based on the new findings provided here and records gathered from literature.

\section{MATERIALS AND METHODS}

\section{TAXON SAMPLING}

The chromosome numbers of 62 species in 17 genera of Bignonieae were determined, eight of 
them were new counts; 16 species whose counts were previously published in the literature were counted again, and 38 species were considered only from published literature. Among them, 18 species had more than one sample included in the analysis. Taxon names including authorities, chromosome numbers, and references are listed on Table SI Supplementary Material.

The heterochromatin banding patterns of 24 species belonging to 12 genera of lianas and shrubs (mostly from northeastern, southeastern, mid-western Brazil) were examined. Taxon names, vouchers, collection sites, vegetation types, and karyological details are listed in Table SII. On the average, three specimens of each species were germinated in plastic pots in the experimental garden of the Centro de Ciências Agrárias of the Universidade Federal da Paraíba. When their roots reached $2 \mathrm{~cm}$ in length, fifteen roots tips per specimen were excised and analyzed.

\section{CYTOGENETIC ANALYSES}

Mitosis was examined in root tips that had been pretreated with $0.002 \mathrm{M}$ 8-hydroxyquinoline (8-HQ) for 24 hours, fixed in Carnoy's solution (absolute ethanol: glacial acetic acid; $3: 1, v / v$ ) for 30 minutes and subsequently stored at $-20^{\circ} \mathrm{C}$. The root tips where then digested in a solution of $2 \%$ cellulase and $20 \%$ pectinase at $37^{\circ} \mathrm{C}$ for 40 minutes. The samples were crushed between slides and coverslips in $45 \%$ acetic acid and subsequently submerged in liquid nitrogen to remove the coverslips. The samples were then stained with DAPI $(2 \mu \mathrm{g} / \mathrm{ml})$ : glycerin $(1: 1, \mathrm{v} / \mathrm{v})$, and the best samples were selected. The samples selected were fixed again in Carnoy's solution (3:1, $\mathrm{v} / \mathrm{v}$ ) for 30 minutes at room temperature, and then kept in absolute ethanol for two hours. The slides were then dried for three days at room temperature, and each sample was subsequently stained with 10 $\mu \mathrm{L}$ of $\mathrm{CMA}(0.1 \mathrm{mg} / \mathrm{mL})$ for one hour and then with $10 \mu \mathrm{L}$ of DAPI $(1 \mu \mathrm{L} / \mathrm{mL})$ for 30 minutes. The slides were mounted with glycerin/ McIlvain buffer at $\mathrm{pH}$ $7,0(1: 1, \mathrm{v} / \mathrm{v})$ and kept in dark for three days (Guerra and Souza 2002).

Images of three slides with at least ten cells in metaphase per slide were captured using an Axio Cam MRC5 digital camera with AxioVision 4.8 software (Carl Zeiss Microscopy GmbH, Jena, Germany). Final documentation was prepared using Photoshop CS3 Extended 10.0 software (Adobe Systems Incorporated, San Jose, USA). Chromosome measurements were made using Image Tool 3.0 software (Donald et al. 2008). Chromosome morphologies were determined using the centromeric index, following Guerra (1986). Classification of the heterochromatin banding patterns followed Guerra (1993) and Cornélio et al. (2003).

\section{RESULTS}

\section{CHROMOSOME NUMBERS}

The chromosome numbers of 62 species of Bignonieae (Bignoniaceae) were analyzed; 55 species $(88.7 \%)$ showed $2 n=40$; six $(9.67 \%)$ showed $2 n=80$, two $(3.22 \%)$ showed $2 n=60$; and two $(3.22 \%)$ showed $2 n=38$. Two species have reported intraspecific variations: Dolichandra unguis-cati $(2 n=40$ and 80$)$ and Pyrostegia venusta $(2 n=40,60$ and 80). Polyploidy was also reported in Anemopaegma $(2 n=60$ and 80$)$, while disploidy has only been reported in Mansoa $(2 \mathrm{n}=38)$ (Table SI).

\section{CYTOGENETIC ANALYSES AND \\ HETEROCHROMATIN PATTERNS}

Most species sampled here were diploids, with $2 n$ $=40$ (Table SII; Figures 1 and 2). Two species were tetraploids (D. unguis-cati and P. venusta, $2 n=80$, Figures 11 and $2 \mathrm{i}$ respectively); one was triploid (Anemopaegma citrinum, $2 n=60$, Figure $1 \mathrm{H}$ ); and one dysploid (Mansoa difficilis, $2 n=38$, Figure $2 \mathrm{~h})$. The karyotypes showed small chromosomes (following Guerra 2000). The mean sizes ranged between $1.36 \mu \mathrm{m}( \pm 0.22)$ in Adenocalymma 

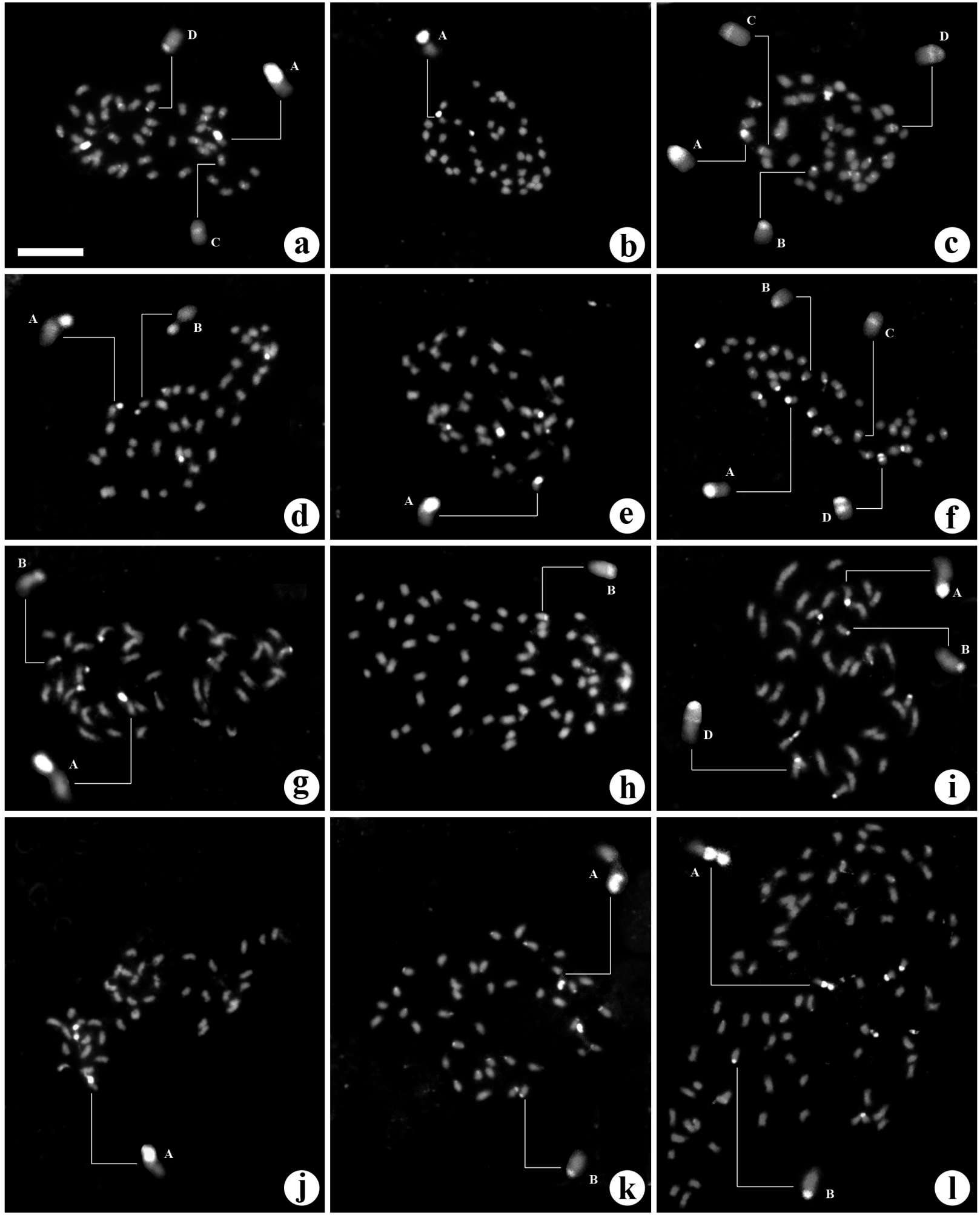

Figure 1 - Distribution of $\mathrm{CMA}^{+}$bands in Bignonieae (Bignoniaceae) species: a. Adenocalymma divaricatum, b. A. imperatorismaximilianii, c. Amphilophium bauhinioides, d. A. crucigerum, e. A. elongatum, f. A. scabriusculum, g. Anemopaegma album, h. A. citrinum, i. A. leave, j. Cuspidaria laterifolia, k. Dolichandra quadrivalvis, l. D. unguis-cati. Scale bar in a corresponds to $10 \mu \mathrm{m}$. 

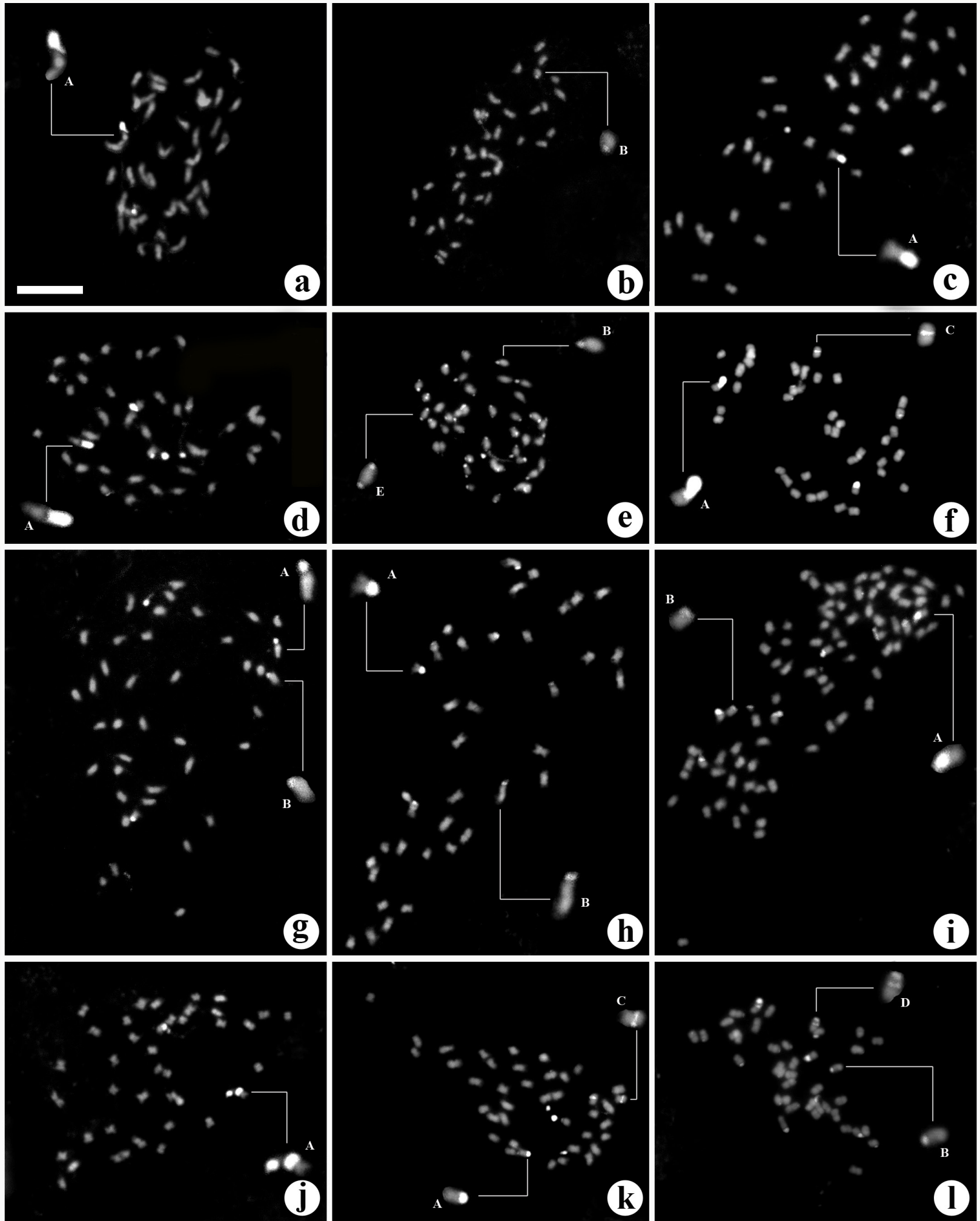

(h)

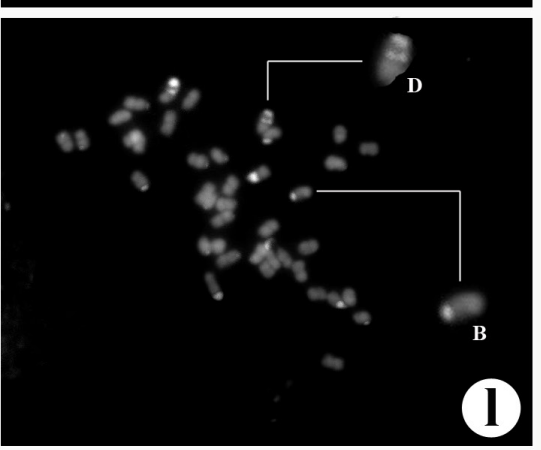

Figure 2 - Distribution of $\mathrm{CMA}^{+}$bands in Bignonieae (Bignoniaceae) species: a. Fridericia dichotoma, b. F. erubescens, c. F. limae, d. F. platyphylla, e. F. pubescens, f. F. subverticillata, g. Lundia longa, h. Mansoa difficilis, i. Pyrostegia venusta, j. Stizophyllum riparium, k. Tanaecium selloi, l. Xylophragma myrianthum. Scale bar in a corresponds to $10 \mu \mathrm{m}$. 
imperatoris-maximilianii and $2.62 \mu \mathrm{m}( \pm 0.42)$ in Anemopaegma laeve (Table SII). The chromosome morphologies were mainly symmetrical for all species, being metacentric or sub-metacentric.

The heterochromatin of all of the species showed exclusively GC-rich bands $\left(\mathrm{CMA}^{+} / \mathrm{DAPI}^{-}\right.$ ), with no AT-rich bands $\left(\mathrm{CMA}^{-} / \mathrm{DAPI}^{+}\right)$being found. The GC-rich bands were observed in the proximal or terminal portions of the chromosome arms (Figures 1 and 2, Table SII). Six patterns were identified among the karyotypes of Bignonieae species based on the sizes and distributions of their chromosomal bands (Figure 3, Table SII): A) one large and distal telomeric band (observed in 19 species); B) one small or very small distal band (in 14 species); C) one small proximal band (in six species); D) two small bands, one being proximal and the other one distal in the same arm of the

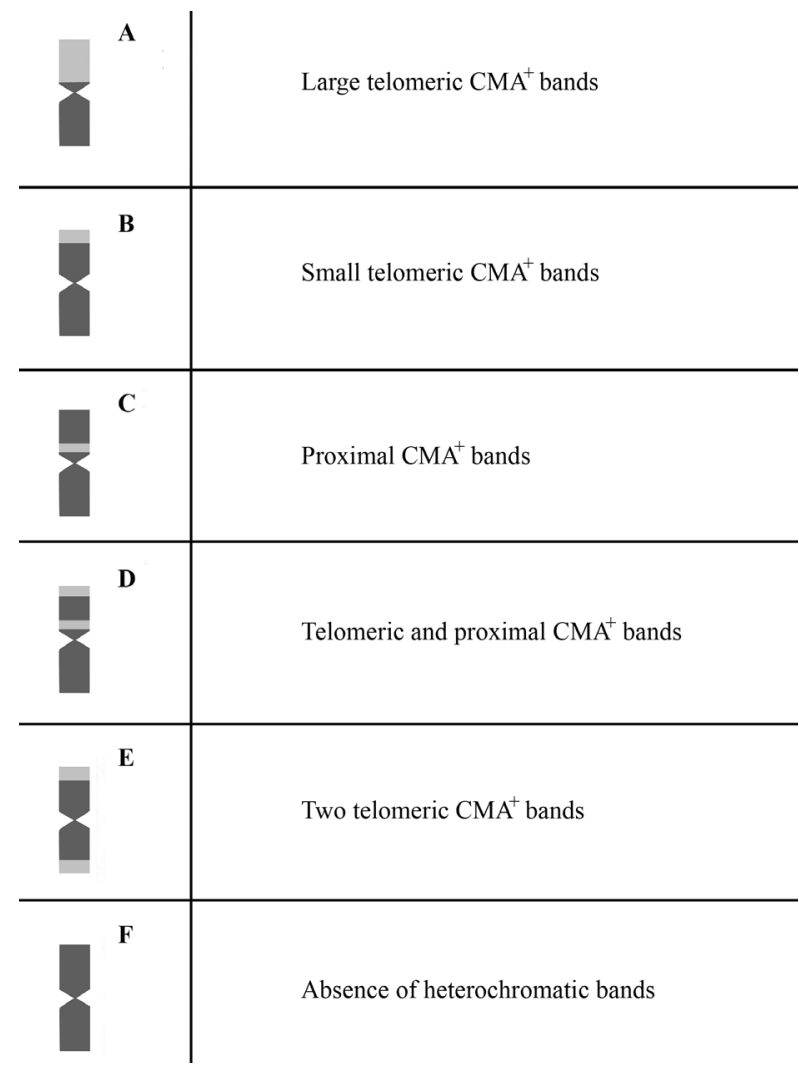

Figure 3 - Main chromosome types in Bignonieae (Bignoniaceae) according to the sizes and positions of the $\mathrm{CMA}^{+}$bands. chromosome (in five species); E) two small distal bands (only in Fridericia pubescens, Figure 2e); and f) a lack of any heterochromatic bands.

\section{DISCUSSION}

The chromosome number $2 n=40$ was found in $\sim 90$ $\%$ of the species of Bignonieae previously analyzed (Table SI). Few species are $2 n \neq 40$, although polyploidy is quite important in Anemopaegma (Firetti-Leggieri et al. 2011, 2013), and disploidy seems to be important in Mansoa. The prevalence of $2 n=40$ has also been observed in other suprageneric groups of the family Bignoniaceae, such as in Catalpeae and the Tabebuia alliance clade (Goldblatt and Gentry 1979, Piazzano 1998). Diploid numbers are variable in other clades of Bignoniaceae, however, such as in the tribes Oroxyleae $(2 n=14$ and 15; Goldblatt and Gentry 1979), in Tecomeae sensu Olmstead et al. (2009) $(2 n=22,36$ and 38; Goldblatt and Gentry 1979, Piazzano 1998, Chen et al. 2004, Piazzano et al. 2015), in Jacarandeae $(2 n=36$; Cordeiro et al. 2016b), and in the genera Argylia D.Don ( $2 n=30$; Goldblatt and Gentry 1979) and Delostoma D.Don $(2 n=42$; Goldblatt and Gentry 1979).

Our data corroborated previous records of chromosome numbers in Bignonieae. Five of seven new records had $2 n=40$ (Adenocalymma divaricatum, Amphilophium scabriusculum, Fridericia limae, F. subverticillata, and Xylophragma myrianthum). Additionally, a new cytotype is described here for the genus Anemopaegma, more specifically for $A$. citrinum $(2 n=60)$, since previous counts for that genus were $2 n=40$ and 80 (Firetti-Leggieri et al. 2011, 2013). Gentry (1973) noted that Anemopaegma is one of the most complicated genera of Bignonieae because of the wide phenotypic plasticity of some species - which has led several authors to consider different phenotypes as different species. Anemopaegma citrinum is restricted to 
dry regions of Brazil, whereas a morphologically close species, A. chamberlaynii (Sims) Bureau \& K. Schum., is widely distributed in South America (see Lohmann and Taylor 2014). Both species show wide variations in leaf and calyx shapes and sizes; it is possible to distinguish between them because of variations in the morphologies of their inflorescences as well as the larger prophylls in $A$. chamberlaynii (smaller or missing in A. citrinum). There different chromosome numbers can also aid in distinguishing between them, with $2 n=40$ in $A$. chamberlaynii (Goldblatt and Gentry 1979, FirettiLeggieri et al. 2011) and $2 n=60$ in A. citrinum. Further studies, including samples from different populations, will still be needed to determine if triploidy is a common feature in $A$. citrinum.

Disploidy is only found in Mansoa $(2 n=$ $38)$ in the Bignonieae. That genus was recently re-circumscribed based on molecular and morphological evidence and now includes species previously placed in Pachyptera, such as Mansoa hymenaea, whereas $M$. difficilis had long been placed in Mansoa (Lohmann and Taylor 2014). The similar chromosome numbers of those two taxa seem to represent additional evidence corroborating the synonymization of most species of Pachyptera into Mansoa.

Some species of Anemopaegma, Dolichandra, and Pyrostegia have putative polyploidy. All known polyploid species of Anemopaegma are from the Brazilian Cerrado and belong to a morphologically similar complex of species named the "Anemopaegma arvense complex" (FirettiLeggieri et al. 2011, 2013). Some samples of $A$. arvense show us a continuum of otherwise distinct morphological features, which may indicate hybridization. Therefore, the $2 n=80$ record probably represents allopolyploidy (Firetti-Leggieri et al. $2011,2013)$. The new record found here of $2 n=$ 60 in a species outside the "Anemopaegma arvense complex" (A. citrinum), on the other hand, may represent the fusion of a regular reduced gamete $(n)$ with an unreduced gamete $(2 n)$ of the same species, generating the triploid sample analyzed here. In addition to $A$. citrinum, $2 n=60$ was also observed in Pyrostegia venusta (Joshi and Hardas 1956). Even though triploids are sterile, triploid gametes can be fertilized by regular reduced gametes $(n)$ and generate fertile tetraploids (Levin 2002). The generation of tetraploids involving triploid bridges is a well known mechanism (see de Wet 1971 for a review study) and can play an important role in generating polyploidy in plants (Soltis et al. 2007, Mason and Pires 2015). Pyrostegya venusta, for example, also has records of $2 n=40$ (Goldblatt and Gentry 1979, Piazzano 1998) and $2 n=80$ (Cordeiro et al. 2016a). This reinforces the hypothesis that polyploidy involving triploid bridges is an evolutionary mechanism acting in Bignonieae.

Another example of polyploidy was recorded for Dolichandra unguis-cati. This species is widely distributed in wet and dry forests in the neotropical region, from the southern United States through Argentina (Lohmann and Taylor 2014). Polyploidy is very common feature of invasive species (see Beest et al. 2012 for a review), and Dolichandra unguis-cati is an important invasive species in Australia, the United Arab Emirates, and South Africa (Fonseca and Lohmann 2015). The records of $2 n=40$ and 80 for this species may have resulted from autopolyploidy, although its sympatric distribution with the closely related species $D$. quadrivalvis, associated with its wide distribution and potential as an invasive plant, suggests allopolyploidy. Further studies involving reproductive biology and population genetics of these closely related species will be essential to understanding how that species has fixed a tetraploid karyotype.

Fluorochromes have been shown to bea powerful cytotaxonomic tool in karyotype analysis. The distinct staining patterns of heterochromatin revealed when using this technique are useful for distinguishing between plant groups with very stable chromosome 
numbers (Guerra 2000). At least six different GCrich band patterns are observed in Bignonieae, and they are usually telomeric. Chromosome type A is the most common pattern, occurring in $79.16 \%$ of the species studied. This large band may be related to nucleolar organizer regions (NORs) because their placement at, or close to, telomeric portions of the chromosomes. Chromosomes types B, C, D and $\mathrm{F}$ were variable in terms of presence/absence and numbers among the different species, and therefore appear to be the most suitable for cytotaxonomic analysis within the Bignonieae. Chromosome type E was the rarest, being observed only in Fridericia pubescens. The variations of the numbers and placements of heterochromatic bands may reflect satellite DNA amplification, retrotransposons, and co-amplification of tandem repeats, and/or other transposable elements (Eickbush and Eickbush 2007, Hobza et al. 2015, Evtushenko et al. 2016). Despite the multitude of mechanisms capable of producing different patterns, variations in heterochromatin patterns have been used to confirm the taxonomic placements of numerous taxa. Citrus is a good example, as the seven chromosomes types described by Guerra (1993) and Cornélio et al. (2003) have been widely used to distinguish between different specimens, cultivars, and hybrids - even species of related genera (Cornélio et al. 2003, Carvalho et al. 2005, Barros e Silva et al. 2010).

According to Guerra (2000), heterochromatin is not homogeneous and may vary qualitatively and quantitatively between taxa, making it potentially useful for taxonomic purposes. Although the species of some genera have constant patterns of heterochromatic bands, such as Crinum (Ahmed et al. 2004), Lycium (Stiefkens et al. 2010), and Pereskia (Castro et al. 2016), no genus of Bignonieae that has had more than one species sampled has been observed to demonstrate any particular banding pattern; identical karyotypes, on the other hand, have been observed in species of distinct genera. The karyotype $2 \mathrm{~A}+38 \mathrm{~F}$, for example, is shared by Adenocalymma imperatorismaximilianii, Cuspidaria lateriflora, Fridericia dichotoma, F. limae, and Stizophyllum riparium; the karyotype $4 \mathrm{~A}+36 \mathrm{~F}$ is shared by F. platyphylla and Amphilophium elongatum; and $2 \mathrm{~A}+2 \mathrm{C}+36 \mathrm{~F}$ is shared by F. subverticillata and Tanaecium selloi. The most common karyotypes are based on chromosomes types $\mathrm{A}, \mathrm{B}$, and $\mathrm{F}$, with variable numbers of types $\mathrm{B}$ and $\mathrm{F}$ (more specifically $2 \mathrm{~A}$ $+2-10 \mathrm{~B}+28-36 \mathrm{~F})$. This karyotype is shared by Amphilophium crucigerum, Anemopaegma album, Dolichandra quadrivalvis, Lundia longa, and Mansoa difficilis. In addition to those taxa, two of the three polyploid species (Dolichandra unguis-cati and Pyrostegia venusta) show the same patterns when the formula is multiplied by the ploidy number. Eleven species have exclusive karyotypes, including Fridericia pubescens (22 $\mathrm{B}+10 \mathrm{E}+8 \mathrm{~F}$ ), with the exclusive chromosome type E. Our results suggest that there are significant variations in heterochromatin banding patterns in the family Bignonieae, although their future utility will depend on further studies, including more samples per species. Wider studies would allow us to better understand variations in the chromosome types of species having the $2 \mathrm{~A}+2-10 \mathrm{~B}+28-36$ F karyotype (i.e., if this karyotype is stable within the same species), and help ensure that there are no variations in the karyotypes of species having exclusive karyotypes. This will certainly be an interesting investigative line to follow.

\section{CONCLUSIONS}

The chromosome number $2 n=40$ is predominant in the cytogenetics of Bignonieae. Some variations were found among the species of Mansoa (possibly due to disploidy [ $2 n=38]$ ), in some species of Anemopaegma and Pyrostegia venusta $(2 n=40$, 60 and 80), and in Dolichandra unguis-cati (2n $=40$ and 80$)-$ possibly due to allopolyploidy or autopolyploidy. 
Staining with the fluorochromes CMA/DAPI demonstrated only $\mathrm{GC}$-rich bands $\left(\mathrm{CMA}^{+} / \mathrm{DAPI}^{-}\right)$in all species. Six chromosomes types were identified based on the sizes and distributions of their heterochromatin bands. Type A chromosomes, have large $\mathrm{CMA}^{+}$and telomeric bands (occurring in $\sim 80 \%$ of the species) that probably represent nucleolar organizer regions (NORs). Chromosome types B, $\mathrm{C}, \mathrm{D}$ and $\mathrm{F}$ were variable in terms of their presence/ absence and numbers of $\mathrm{CMA}^{+}$bands among the different species, and therefore may be suitable for cytotaxonomic analyses of Bignonieae species.

No genus of Bignonieae with more than one sampled species showed a unique banding pattern, and similar karyotypes were occasionally observed in species from distinct genera. Therefore, there are variations in heterochromatin bands in the Bignonieae, but the utility of those analyses will still depend on further studies to ensure that the karyotypes are stable within the same species and that there are no variations in the karyotypes of species that show exclusive karyotypes.

\section{ACKNOWLEDGMENTS}

We thank the Conselho Nacional de Desenvolvimento Científco e Tecnológico (CNPq) and the Coordenação de Aperfeiçoamento de Pessoal de Nível Superior (CAPES) for financial support, and the Instituto Nacional do Semiárido (INSA) for their technical support.

\section{REFERENCES}

AHMED L, BEGUM R, NOOR SS, ZAMAN MA AND ALAM SS. 2004. Reversible fluorescent chromosome banding in three Crinum spp. (Amaryllidaceae). Cytologia 691: 69-74.

ALMEIDA CCS, CARVALHO PCL AND GUERRA M. 2007. Karyotype differentiation among Spondias species and the putative hybrid umbu-cajá (Anacardiaceae). Bot J Linn Soc 155: 541-547.

ALMEIDA EM, WANDERLEY AM, NOLLET F, COSTA FR, SOUZA LGR AND FELIX LP. 2016. A new species of Ameroglossum (Schrophulariaceae) growing on inselbergs in Northeastern Brazil. Sist Bot 41: 423-429.

BARROS E SILVA AE, MARQUES AS, KARLA GB AND GUERRA M. 2010. The evolution of CMA bands in Citrus and related genera. Chromosome Res 18: 503-514.

BEEST M, ROUX JJL, RICHARDSON DM, BRYSTING AK, SUDA J, KUBEŠOVÁ M AND PYŠEK P. 2012. The more the better? The role of polyploidy in facilitating plant invasions. Ann Bot 109: 19-45.

BEGUM KN AND ALAM SS. 2016. Differential fluorescent banding in nine varieties of Cicer arietium L. Cytologia 81: 383-387.

CARVALHO R, SOARES FILHO WS, BRASILEIROVIDAL AC AND GUERRA M. 2005. The relationships among lemons, limes and citron: a chromosomal comparison. Cytogenet Genome Res 109: 276-282.

CASTRO JP, MEDEIROS-NETO E, SOUZA G, ALVES LIF, BATISTA FRC AND FELIX LP. 2016. CMA band variability and physical mapping of $5 \mathrm{~S}$ and $45 \mathrm{~S}$ rDNA sites in Brazilian Cactaceae: Pereskioideae and Opuntioideae. Braz J Bot: 613-620.

CCDB - CHROMOSOME COUNTS DATABASE. 2017. Available at: http://ccdb.tau.ac.il/ (Accessed December 23, 2016).

CHEN ST, ZHOU ZK, GUAN KY AND NAKATA M. 2004. Karyomorphology of Incarvillea (Bignoniaceae) and its implications in distribution and taxonomy. Bot $\mathrm{J}$ Linn Soc 144: 113-121.

CORDEIRO JMP, ALMEIDA EM, LIMA SAA, ASSIS FNM, SOUZA LGR AND FELIX LP. 2016a. In: Marhold K and Kučera J (Eds), IAPT/IOPB chromosome data 23. Taxon 65: 1455-1458.

CORDEIRO JMP, LIMA SAA, PAZ SN, SANTOS MAS AND FELIX LP. 2016b. Karyotype evolution in the genus Jacaranda Juss. (Jacarandeae, Bignoniaceae): chromosome numbers and heterochromatin. Genet Mol Res 15: gmr15048973.

CORDEIRO JMP, PAZ SN, SANTOS AMS, MEDEIROS NETO E, SANTOS A, ASSIS FNM AND FELIX LP. 2017. In: Marhold K and Kučera J (Eds), IAPT/IOPB chromosome data 24. Taxon 66: 275-277.

CORNÉLIO MTMN, FIGUEIRÔA ARS, SANTOS KGB, CARVALHO R, SOARES FILHO WS AND GUERRA M. 2003. Chromosomal relationship among cultivars of Citrus reticulata Blanco, its hybrids and related species. Plan Syst Evol 240: 149-161.

DE WET JMJ. 1971. Polyploidy and evolution in plants. Taxon 20: 29-35.

DEMATTEIS M, FERNÁNDEZ A AND ACOSTA AD. 2006. Heterochromatin variation in Oziroë argentinensis (Hyacinthaceae) revealed by florescent banding. Caryologia 59: 104-111. 
DONALD C, BRENT DS, MCDAVID WD AND GREER DB. 2008. Uthscsa. Image Tool (IT) - Version 3.0. Available at: http://ddsdx.uthscsa.edu/dig/download.html (accessed April 10, 2017).

EICKBUSH TH AND EICKBUSH DG. 2007. Finely orchestrated movements: Evolution of the ribosomal RNA genes. Genetics 175: 477-485.

EVTUSHENKO EV, LEVITSKY VG, ELISAFENKO EA, GUNBIN KV, BELOUSOV AI, ŠAFÁŘ J, DOLEŽEL J AND VERSHININ AV. 2016. The expansion of heterochromatin blocks in rye reflects the co-amplification of tandem repeats and adjacent transposable elements. BMC Genomics 17: 337.

FIRETTI-LEGGIERI F, COSTA IR, LOHMANN LG, SEMIR J AND MARTINS ERF. 2011. Chromosome studies in Bignonieae (Bignoniaceae): The first record of polyploidy in Anemopaegma. Cytologia 76: 185-191.

FIRETTI-LEGGIERI F, LOHMANN LG, ALCANTARA S, COSTA IR AND SEMIR J. 2013. Polyploidy and polyembryony in Anemopaegma (Bignonieae, Bignoniaceae). Plant Reprod 26: 43-53.

FONSECA LHM AND LOHMANN LG. 2015. Biogeography and evolution of Dolichandra (Bignonieae, Bignoniaceae). Bot J Linn Soc 179: 403-420.

GENTRY AH. 1973. Bignoniaceae. In: Woodson Jr RE and Schery RW (Eds), Flora of Panama 9 (fam. 172). Ann Missouri Bot Gard 60: 781-997.

GENTRY AH. 1980. Bignoniaceae. Part I. Tribes Crescentieae and Tourretieae. Flora Neotropica Monograph 25(1): $1-131$.

GOLDBLATT P AND GENTRY AH. 1979. Cytology of Bignoniaceae. Bot Notiser 132: 475-482.

GOLDBLATT P AND JOHNSON DE. 1990. Index to plant chromosome numbers 1986-1987. Monographs in Systematic Botany. Missouri Botanical Garden 30: 1-243.

GUERRA M. 1986. Reviewing the chromosome nomenclature of Levan et al. Rev Brasil Genet 9: 741-743.

GUERRA M. 1993. Cytogenetics of Rutaceae. V. High chromosomal variability in Citrus species revealed by CMA/DAPI staining. Heredity (Edinburgh) 71: 234-241.

GUERRA M. 2000. Patterns of heterochromatin distribution in plant chromosomes. Genet Mol Biol 23: 1029-1041.

GUERRA M AND SOUZA MJ. 2002. Como observar cromossomos: um guia de técnicas em citogenética vegetal, animal e humana. FUNPEC-Editora, Ribeirão Preto: São Paulo, 131 p.

HOBZA R, KUBAT Z, CEGAN R, JESIONEK W, VYSKOT B AND KEJNOVSKY E. 2015. Impact of repetitive DNA on sex chromosome evolution in plants. Chromosome Res 23: 561-570.

JOSHI AB AND HARDAS MW. 1956. Ploidy in two bignoniaceous garden climbers. Indian $\mathrm{J}$ Genet $\mathrm{Pl} \mathrm{Br} 16$ : 57-59.
LEVIN DA. 2002. The role of chromosomal change in plant evolution. Oxford University Press, Oxford, $240 \mathrm{p}$.

LOHMANN LG. 2006. Untangling the phylogeny of Neotropical lianas (Bignonieae, Bignoniaceae). Am J Bot 93: 304-318.

LOHMANN LG AND TAYLOR CM. 2014. A new generic classification of tribe Bignonieae (Bignoniaceae). Ann Missouri Bot Gard 99: 348-489.

LOHMANN LG AND ULLOA CU. 2017. Bignoniaceae. In: iPlants prototype Checklist. Available at: www.iplants.org (Accessed May 14, 2016).

MASON AS AND PIRES JC. 2015. Unreduced gametes: meiotic mishap or evolutionary mechanism? Trends Genet 31: 5-10.

MOORE RJ. 1974. Index to plant chromosome numbers for 1972. Regnum Veg 91: 1-108.

OLMSTEAD RG, ZJHRA ML, LOHMANN LG, GROSE SO AND ECKERT AJ. 2009. A molecular phylogeny and classification of Bignoniaceae. Am J Bot 96: 1731-1743.

PIAZZANO M. 1998. Números cromossômicos em Bignoniaceae de Argentina. Kurtziana 26: 179-219.

PIAZZANO M, LAS PEÑAS ML, CHIARINI F AND BERNARDELLO G. 2015. Karyotypes and DNA content in Bignoniaceae. Caryologia 68: 175-183.

ROMERO-DA CRUZ MV, URDAMPILLETA JD, FORNI MARTINS ER AND MOSCONE EA. 2015. Cytogenetic markers for the characterization of Capsicum annum L. cultivars. Plant Biosyst 151: 84-91.

SIMMONDS NW. 1954. Chromosome behavior in some tropical plants. Heredity 8: 139-146.

SOLTIS DE, SOLTIS PS, SCHEMSKE DW, HANCOCK JF, THOMPSOM JN, HUSBAND BC AND JUDD WS. 2007. Autopolyploidy in angiosperms: have we grossly underestimated the number of species? Taxon 56: 13-30.

STIEFKENS L, LAS PEÑAS ML, BERNARDELLO G, LEVIN RA AND MILLER JS. 2010. Karyotypes and fluorescent chromosome banding patterns in southern African Lycium (Solanaceae). Caryologia 63: 50-61.

\section{SUPPLEMENTARY MATERIAL}

TABLE SI - Chromosome numbers recorded for the tribe Bignonieae and their respective bibliographic references.

TABLE SII - Species of the tribe Bignonieae (Bignoniaceae) analyzed and their main karyological parameters. Legend: A - large telomeric $\mathrm{CMA}^{+}$bands, $\mathrm{B}$ - small telomeric $\mathrm{CMA}^{+}$ bands, $\mathrm{C}$ - proximal $\mathrm{CMA}^{+}$bands, $\mathrm{D}$ - telomeric and proximal $\mathrm{CMA}^{+}$bands, $\mathrm{E}$ - two telomeric $\mathrm{CMA}^{+}$ bands, $\mathrm{F}$ - absence of heterochromatic bands. 